\title{
Narrativa cinematográfica y deliberación: algunas reflexiones sobre la enseñanza de la bioética en la universidad
}

Trombert, Alejandro R. ${ }^{1}$; Chartier, M. Eugenia ${ }^{1,2}$

\section{Resumen}

La reflexión sobre la educación en Bioética ha cobrado en la actualidad una importancia destacable. Siendo una disciplina surgida a partir del reconocimiento de la conflictividad creciente de las sociedades occidentales contemporáneas, y teniendo que dar cuenta de problemas nuevos, con respuestas inéditas, ha manifestado desde temprana edad una preocupación por lo metodológico.

El reconocimiento de la diversidad y la aceptación del pluralismo, vinculado a la valoración de la libertad humana para decidir sobre su propia vida y el consecuente desafío de promover y garantizar la autonomía, invitan a la búsqueda de criterios racionales para la resolución de conflictos.

En el presente trabajo, tomando como referencia el método de razonamiento ético elaborado por la UNESCO, nos proponemos emprender un proceso reflexivo a partir de una metodología didáctica sustentada en el lenguaje cinematográfico como narrativa que posibilita la indagación reflexiva de los problemas éticos y favorece los procesos deliberativos.

La apelación al cine supone recurrir al lenguaje visual y auditivo como un modo privilegiado de plantear situaciones problemáticas a partir de un lenguaje que abre infinitas posibilidades para la comprensión de la realidad, a partir de procesos cognitivos que abarcan las emociones, convirtiendo al cine, en una experiencia narrativa.

Palabras clave: bioética, cine, educación, narrativa, deliberación

\footnotetext{
${ }^{1}$ Facultad de Bioquímica y Ciencias Biológicas, Universidad Nacional del Litoral, Santa Fe, Argentina. atrombert@fbcb.unl.edu.ar

2 Facultad de Ingeniería, Universidad Nacional de Entre Ríos, Oro Verde, Entre Ríos, Argentina.

mechartier@unl.edu.ar
} 


\section{Summary}

Reflection on Bioethics Education has gained a remarkable importance nowadays. Being bioethics a discipline that has emerged from the recognition of the growing conflict in contemporary western societies, and having to face new problems, with untold answers; bioethics has expressed methodological concerns.

The recognition of diversity and the acceptance of pluralism, linked to the value of human freedom to decide about life, and the consequent challenge of promoting and ensuring autonomy, motivate the search of rational criteria for conflict's resolution.

In this contribution, considering the method of ethical reasoning produced by the UNESCO's Program for the Study of Bioethics, we propose to undertake a reflective process from a didactic methodology based on the film language as a narrative which enables the reflective examination of ethical problems and promotes deliberative processes.

The appeal to the film involves the use of visual and auditory languages, which are accepted today, even in some cases with priority over written language. We consider this approach as a privileged way of posing problem situations from a language that opens up endless possibilities for understanding reality, taking into account cognitive processes involving emotions and turning the film into a narrative experience.

Keywords: bioethics, cinema, education, narrative, deliberation 